\title{
Marketing Information Systems and Competitive Advantage at Consolidated Bank of Kenya Limited
}

\author{
Joyce Thuita and Winnie Njeru
}

\section{ABSTRACT}

Business today is a challenge because of the dynamics involved, marketers whose responsibility is to ensure that the business makes profits also have to be dynamic on how they organize their marketing strategies in a way that is relevant to today's market. Whatever the kind of establishment, market and purchaser information is necessary if organization objectives are to be met and consumers needs fulfilled, having an efficient marketing information system is one of the channels through which an organization can acquire the information it needs from its customers thereby giving the organization competitive advantage. This study therefore sought to establish the impact of marketing information systems on competitive advantage at Consolidated Bank of Kenya Limited. The study used a case study. Primary data was collected using an interview guide and data collected from the heads of departments particularly from marketing, alternative business channels and business development, who are highly involved in formulation and implementation of strategy. Content analysis was used to analyze the data. The study established that the marketing environment in the banking industry is very competitive and therefore marketers must adapt to the ever-changing marketing environment. Further, improvements in the bank's products, services and the brand image have enhanced competitive advantage of the bank. Finally, the study also revealed that Marketing Information Systems are of value to the organization. In conclusion the study established that the company has in place a marketing information system which the bank uses to acquire relevant information from customers, which is in turn used to develop products and services that meet the customer's needs while still maintaining lower costs. The study recommends that management should ensure continued improvement in the marketing information system to enable the bank to maintain sustainable competitive advantage. There need for management to set aside resources and invest in marketing information systems to enable the bank to compete effectively in its marketing environment.

Keywords: competitive advantage, Consolidated Bank, marketing environment, marketing information systems, marketing strategies.

Submitted : August 29, 2021

Published : October 26, 2021

ISSN: 2507-1076

DOI: $10.24018 /$ ejbmr.2021.6.5.1077

Joyce Thuita*

MBA graduate, Faculty of Business and

Management Sciences, University of

Nairobi, Kenya.

(e-mail: joycethuita@rocketmail.com)

Dr. Winnie Njeru

Lecturer, Faculty of Business and

Management Sciences, University of

Nairobi, Kenya.

(e-mail: winnie.njeru@uonbi.ac.ke)

*Corresponding Author

\section{INTRODUCTION}

Business today is a challenge because of the many dynamics involved. Marketers, who have the sole responsibility of ensuring the business makes profits and achieve the overall organizations objectives need to be dynamic in how they organize their marketing strategies in a competitive way, which is relevant to today's market, taking into consideration all the current trends in today's marketing environment [1]. Whatever the kind of establishment, market and customer information is vital if organizational objectives are to be accomplished and customer needs and wants fulfilled. Having an effective Marketing Information Systems is one way in which an organization can acquire the information if they are to succeed in formulating marketing policies. A competitive advantage is that group of special characteristics an organization has, that are viewed by the target market as important and superior to its competitors.

The banking sector is starting to integrate the characteristics and methods that were once the scope of financial technology startups. Banks are now embracing the quicker pace of invention, using information and analytic data more broadly and digitization procedures. The banking industry has been a key driver of the economy of Kenya [2]. Consolidated Bank of Kenya has been one of the banks that has embraced new technological developments and uses them to ensure that it offers services and products that will satisfy consumer needs and thus enabling the bank to enjoy its share in the entire banking industry. To enable managers, predict the future market changes and consumer behavior an organization needs a clear MKIS [3]. 
The banking sector has been the major driving force of Kenya's economy placing it in front of its neighbouring countries. The Central Bank of Kenya (CBK) is the principal controller of this industry. CBK categorizes commercial banks according to their resources. Tier 1 banks are those banks that are colossal and have billions in wealth and have little chance of collapsing commercially. Tier 2 banks are the intermediate ones while tier 3 banks comprise of small banks.

Consolidated Bank of Kenya Limited was founded in 1989. This was in an attempt to secure the financial field industry through acquiring of nine institutions that were in receivership and subsequently reorganizing them into a feasible, professionally managed commercial bank. The bank is completely owned by the Government of Kenya which has the majority share contribution $(85.81 \%)$ The remainder of the shareholding is disseminated over twenty five parastatals and other semi government institutions, [4].

\section{RESEARCH PROBLEM}

The information change is taking place in all sectors of the economy and no organization can avoid its effects. Instant reductions in the costs of getting, analyzing and transmission of information is changing the way organizations run their business. Progress made in information technology affects competition and is the source of competitive advantage. The information revolution affects competition faced by organizations in three ways: Firstly, it alters the structure of the industry and therefore changing the dynamics of competition. It also provides business enterprises with the most cost-effective ways to perform better than their competitors and opens up new business opportunities.

Several studies have been carried out in relation to marketing information systems and competitive advantage. Queiroz and Oliveira [5] carried out a study on the MKIS in Sao Paulo Brazil in the clothing sector. The study used a case study research design where primary data was sought from two respondents per company. The findings of the study indicated that information and its application in systems are highly important in the advancement of the operational and promotion of new business frontiers. Mohamed [6] carried out a study of Jordan's road transport sector. The study examined the impact of MKIS primary elements that is, interior reporting systems, marketing information systems and marketing research systems on the transport company's performance in Jordan. The population of study included four of Jordan's road transport firms. Data were gathered through a questionnaire to a selected random sample. The findings indicated that there was a statistically important effect on the productivity of road transport companies in Jordan, by better performance with varying levels. The study concluded that firms with effective MKIS prompt organizations performance by developing competitive transport services that meet passenger's expectations and satisfaction.

On their part, Mitchell and Sparks [7] did a study of six UK major banks and proposed desirable components and linkages of sophisticated marketing information systems for financial institutions. The study revealed that most banks were not utilizing IT in MKIS effectively. The study did not emphasize on the broad spectrum of MKIS, its major emphasis was on IT in MKIS. In addition, Kubiak and Kowalik [8] carried out a study on MKIS as a driver of a business enterprises competitive advantage. Primary and secondary data were used for this study. The findings of the initial research revealed a broad spectrum of MKIS intricacy in the studied companies emphasize the significance of market information movement efficiency.

Berhan and Kitaw [9] carried out a study on the role of MKIS in service quality in Ethiopian Industries. The study targeted 42 industries in Ethiopia. The findings of the study revealed that information processing has a great effect and positively determines the service quality and functions of the business. Kimani [10] did a case study on the application of MKIS at Savings and Loan (Kenya) Limited. The study concluded that Savings and Loan (Kenya) Limited had put in place a MKIS in the marketing department and all elements of the marketing information system were implemented. The study sought to establish market information systems and competitive advantage at Consolidated Bank of Kenya Limited.

\section{THEORETICAL FOUNDATION}

The research was anchored on Marketing Information Systems Theory [11], which assumes that with growing competition and widening market, the volume of information required daily by a business is intense; MKIS provide several advantages to any organization. These include enabling an organization to have systematic data gathering, arrange its database accordingly and therefore enhancing efficiency. In addition, a MKIS aids the organization in the storing of important information, thus playing an important part in implementation of marketing strategies.

The study was also anchored on the competitive advantage theory [12]. The theory assumes that a firm can possess either of the two fundamental types of competitive advantage low cost or differentiation [13]. The two types of CA together with the range of operations an enterprise strives to accomplish leads to three generic strategies for achieving better than average performance in its sector, this includes cost leadership, differentiation, and focus [12]. In cost leadership, an organization seeks to become a costeffective producer in its sector, a cost effective producer must identify and take advantage of all sources of financial benefit, In differentiation strategy an enterprise aims to be different in its sector along some extents that are broadly appreciated by customers. An organization's cost focus takes advantage of the disparities in cost behavior in the intended segments while differentiation focus endeavors to harness the unique requirements of purchasers in a particular segment.

\section{DIMENSIONS OF MARKETING INFORMATION SYSTEMS}

The constituents of a MKIS are internal reporting systems (IR), marketing research (MR), marketing intelligence (MI) and marketing decision support systems (MDSS). IR system 
comprises information that is retrieved from businesses that have been operational for a long duration of time. The information is essential for the subsequent prediction which is feasible only by researching and reviewing the previous and current outcomes. The purpose of marketing intelligence/ information system is to gather the latest information about the external marketing context. The Marketing Decision support system purpose is to assist the marketing managers do analysis on the data collected or given through the subsystems of the MKIS and thereby to make sound marketing decisions.

\section{MARKETING INFORMATION SYSTEMS AND COMPETITIVE ADVANTAGE}

Several empirical studies have been carried out in reference Marketing Information Systems and competitive advantage. Ismail [3] carried out research on the role played by marketing information systems in making decisions; the study was applied to the Royal Jordanian Airlines RJA. The aim of the study was to highlight the importance of employing marketing information systems on making of decisions as a consequence of saving time and prevention of duplication of tasks the empirical research findings confirmed that there is a positive relationship between the level of employing and adopting of the marketing information system and the achievement of an organization decision taking and provides the business enterprise with competitive advantage as it permits the organization to solve problems.

Ghazi et al. [14] carried out a research on, the link between MKIS and decision making of the strategic level of banks The study investigated the contribution of MKIS to making better strategic decisions in the Jordanian banking industry consequently achieving competitive advantage and mitigating risks based on MKIS information, a quantitative approach using statistical methods was employed to analyze the data by a questionnaire survey the study concluded that the tactical implementation of MKIS in Jordanian banking sector was employed however it has not been advanced to a strong strategic role which would support the banks performance through risk reducing decision making. Thus, any MKIS, in the Jordanian banking industry is not strategically employed. Kubiak and Kowalik [8] carried out a study on MKIS as a driver of a business enterprises competitive advantage. Primary and secondary data was used for this study. The outcome of the study confirmed the need of MKIS in a company's thought of rationale. The findings of the initial research revealed a broad spectrum of MKIS intricacy in the studied companies emphasize the significance of market information movement efficiency. Berhan and Kitaw [9] carried out a study on the role of MKIS in service quality in Ethiopian Industries. The research was quantitative in nature of 42 industries in Ethiopia. According to their findings acquisition of data and information technology infrastructure greatly supported the information process. Information processing thus has a great effect and positively determines the service quality and functions of the business, but functions of business that utilized data that has already been processed and also information for its functions for example, planning was not established to be an important predictor of service quality.

Ezekiel et al. [15] carried out research of MKIS as a contributing factor in the operation of chosen transport businesses in Calabar metropolis. The research study sought to determine the impact of IR keeping as contributing element in the making of decision and also to assess the degree to which marketing information (MI) has rendered on the performance of chosen public transport by road transport companies in Calabar, data was gathered using questionnaires the study used exploratory and survey research method, the data was analyzed by use of (ordinary least method) OLS. The findings showed that internal records IR and marketing research MR were contributing components to the operations of public road transport companies in Calabar, cross river state in Nigeria. The research also suggested that the MKIS should be employed as the basis of analyzing segmenting, targeting, and positioning and also analysis of competitors. From the reviews it can be deduced that MKIS is essential for decision making. The findings indicate that an organization can obtain competitive advantage by putting in place effective and efficient marketing information systems. The empirical studies also confirmed positive relationships between the level of utilizing and adopting marketing information, and the success of an organizations decision making. In addition, Ghazi et al. [14] who provided a theoretical and empirical understanding of the relationship between MKIS and better decision making at the strategic level of banks.

\section{RESEARCh METHOdOLOGY}

This research adopted a case study research design. Primary data were collected through an interview guide. The respondents were three senior bank managers drawn from the retail Marketing and alternative Business channels and Business Development departments. Content analysis was used to analyze the data.

\section{A. Data Analysis}

The study sought to establish the respondent's demographic information. The results revealed that there were 2 female and 1 male managers. The results established that one manager had a bachelor's degree while two managers had a master's degree. The length of continuous service indicated that 2 managers had worked in the bank for 2 years while 1 manager had more than 10 years work experience in the bank

\section{RESULTS}

The findings of the study revealed that the marketing environment is highly competitive and facing technological advancements with the newest frontiers having been the channels of communication. The following were notable over the seven year period. The bank had embraced technology thus easing customer's level of transaction; the bank had used technology to reduce operational costs but still meet customers' needs as required. The communication channels had also improved with the Bank adopted different 
channels of communication such a short messaging service, social media platforms such as twitter, face book, website which offers a platform to engage with customers. internet banking, Agency banking, USSD, POS Point of sale machines, 24 hour ATMs, credit and debit cards among others channels. This demonstrates a complete change from the traditional banking customer interface thus providing customers with key banking services that are readily accessible.

The study further revealed that there has been a gradual change from the manual collection to the automated collection of information; for example, through face book and twitter which reduces customer's turnaround time for services required. On financial implication, embracing technology is cheaper in the long run as it has led to lower costs. There has also been increased efficiency in data analysis as the company has databases which contain all the pertinent information about its customers. The Bank has continually used Google analytics, which deduces customer demographics and also provides a platform to collect and disseminate information to its customers. The study findings indicated that all the elements of MKIS are used at Consolidated Bank of Kenya. In terms of marketing communication, the Bank has increased the scope for advertising, using a wide range of channels to advertise its products and services. The Bank has witnessed an increase of face book followers from 2,000 in 2016 to 9,300 in 2019 while on twitter the number stands at 1,200 from 500 in 2016. Other applications that have been introduced as a result of responding to information collected from customers include a customer help desk, focus group discussions which are an improvement on how the bank handles its customer complaints from all branches and networks. For example, on Twitter, issues are collected and directed to a dedicated set of employees, the introduction of my-conso app, which offers a platform for communication between the bank and its customers.

The respondents were also in agreement that MKIS has led to the Bank achieving a competitive advantage. The results indicate that the more efficient the MKIS the more an organization is able to develop its processes faster and adapt to the changing marketing environment. The interviewees agreed that the adoption of MKIS has been of great value to the bank in terms of increasing efficiency in terms of addressing customer queries, communication between the customers and the bank is faster through social media platforms such as twitter and face book.

The study sought to determine the influence of marketing information systems on competitive advantage at Consolidated Bank of Kenya Limited. The study confirms that marketing information systems are of great value to the organization. MKIS ensures that a Bank obtains pertinent information about their customers and the environment and thereby is able to create goods and services that meet customers' needs and wants and are able to respond to customer queries promptly thus gaining a competitive advantage. From the study, it was confirmed that the marketing environment in the banking industry is very competitive and dynamic; marketers therefore need to be responsive as well. Having an efficient MKIS is one of the keyways for the bank to be able to gain a competitive advantage in its industry. The study hence advocates for continued improvements in MKIS to enable them to maintain competitive advantage. Furthermore, the study also recommends that the bank should place more emphasis on the marketing intelligence element of the MKIS in collecting happenings data. The study was carried out at Consolidated Bank of Kenya Limited which is government parastatals further studies can be carried out on other private and public organizations.

\section{REFERENCES}

[1] A. M. Ibrahim, "Brand Rejuvenation Strategies and Organization Performance,". 2012. Retrieved September 27th, 20, from Brand Rejuvenation Strategies and Organization Performance: http://erepository.uonbi.ac.ke:80180xml/handle/12345789/13010.

[2] Fadoua, East Africa, Financal Services. Overview of the Kenyan banking sector, p. 1, 2014. fao.org. (n.d.). fao.org. Retrieved October 5, 2019, from fao.org: http://www.fao.org/3/w3241e/w3241e0a.htm\#TopOfPage.

[3] D. T. Ismail, "The role of Marketing Information System on Decision Making. "An Applied Sudy on Royal Jordanian Ailines(RJA)"," International Journal of Business and Social Science, pp. 1-185, 2018.

[4] Consoliadated Bank of Kenya Limited. (Copyright 1989-2019). Consolidated Bank-Growing with you. Retrieved September 27, 2019, from Consolidated Bank-Growing with you: http://www.consolidated-bank.com.

[5] Josimeire Pessoa de Queiroz, Brauli Oliveira, "Benefits of the Marketing Information System in the Clothing Retail Business,' Journal of Information Sytems snd Technology Management, vol. 11, no. $1,2014$.

[6] A. Mohamed, "The effectiveness of Marketing Information System (MKIS) on organizational performance: The case of Jordan's road transport sector", 1, 2018.

[7] J. W. Mitchell, L. Sparks, "Marketing Information Systems in the Major UK Banks," International Journal of Bank Marketing, Vol. 6 No. 5, pp. 14-28, 1988

[8] Bernard F. Kubiak, Micha 1 F. Kowalik, "Marketing Information Systems As A Driver Of An Organization Competitive Advantage," Journal of Internet Banking and Commerce, vol. 15, no. 3, pp. 1-10, 2009.

[9] E. Berhan, D. Kitaw, "The role of Marketing Information systems (MKIS) in service quality in Ethiopian industries," South African Journal of Industrial Engineering, vol. 23, no. 1, pp. 66-76, 2009.

[10] E. W. Kimani, "Application of Marketing Information Systems By Savings And loan (Kenya) Limited in creating Sustainable competitive Advantage," Kenya, 2006.

[11] Gilorkar.R. (n.d.). Econimic Discussion. Net. Retrieved October 5th, 2019, from Marketing Information System: Introduction, Importance, Components and Advantages: http://www.economicsdiscussion.net/marketing-2/marketinginformation-system-introduction-importance-components-andadvantages $/ 31600$.

[12] M. E. Porter, “Competitive Avantage," In M. E. Porter, (pp. 11-15). New York: Free Press, New York, 1985.

[13] M. E. Porter, V. E. Miller, "How Information Gives You Competitive Advantage," In M. E. Millar, How Information Gives You Competitive Advantage. Cambridge, Massachusetts,: Wall Street Journal, 1985.

[14] Ghazi Al-Weshah, Jonathan H Deacon, "The Role of Marketing Information Systems in Making Better Decisions: Evidence from Jordanian Banking Industry," Conference: Academy of Marketing Annual ConferenceAt: Leeds, UK, Vol. 7-10, pp, 1-14, July 2009.

[15] M. Ezekiel, J. F. Eze, Joseph A. Anyadighibe, "A Study of Marketing Information System MIS As a Contributory Factor in Selected Transport Companies in Calabar Metropolis," 2013. 